\title{
PENGEMBANGAN SUMBER DAYA MANUSIA DI INSTITUT AGAMA ISLAM NEGERI (IAIN) BENGKULU MELALUI PENDEKATAN MOTIVASI
}

\author{
Syaifuddin \\ Dosen Fakultas Ekonomi Dan Bisnis Islam IAIN Bengkulu \\ Email: syaifuddinbkl2017@gmail.com
}

\begin{abstract}
Human Resources development has an important role in improving employee performance and productivity. In developing human resources, it can be done using a work motivation approach where work motivation is an impulse to do something consciously that arises from within and outside of each individual with the aim of increasing superior and competitive human resources. In the work motivation there are 6 motivational theories including: Need theory from Abraham Maslow, (b) Frederick Herzberg's two-factor theory, (c) McClelland's Achievement Theory, (d) Strengthening Theory (e ) Expectancy Theory, (f) Purpose Theory as Motivation. Based on this theory a leader can do various things to improve employee motivation and work to improve work productivity because with high motivation, work productivity will also be high and vice versa because between the two will be interrelated.
\end{abstract}

Keywords: Development, Human Resources, Motivation Approach

\section{PENDAHULUAN}

Pengembangan SDM (Sumber Daya Manusia), merupakan suatu kegiatan yang seharusnya dilakukan oleh suatu institusi. Pada dasarnya kegiatan pengembangan SDM didesain guna membantu para pekerja/karyawan/pegawai dengan tujuan memperbaiki kapasitas produktif dari manusia.

Pengembangan Sumber Daya Manusia (SDM) merupakan hal yang sangat vital untuk dilakukan oleh suatu institusi karena dengan adanya pengembangan SDM maka institusi yang bersangkutan berarti telah melakukan adaptasi terhadap lingkungan dan perkembangan demi mencapai SDM yang berkualitas. Dengan SDM yang berkualitas tentu saja akan meningkatkan produktivitas kerja dari suatu institusi. Pengembangan karyawan merupakan unsur penting dari berbagai upaya institusi untuk bersaing pada perekonomian yang baru, memenuhi tantangan persaingan global dan perubahan sosial, menyertakan kemajuan teknologi 
dan perubahan perancangan pekerjaan (Noe et all, 2014).

Sumber daya manusia (SDM) merupakan salah satu faktor penting dalam pembangunan. Secara makro, faktor-faktor masukan pembangunan, seperti sumber daya alam, material dan finansial tidak akan memberi manfaat secara optimal untuk perbaikan kesejahteraan rakyat bila tidak didukung oleh memadainya ketersediaan faktor SDM, baik secara kualitas maupun kuantitas. Pelajaran yang dapat dipetik dari berbagai negara maju adalah, bahwa kemajuan yang dicapai oleh bangsa-bangsa di negara-negara tersebut didukung oleh SDM yang berkualitas. Jepang, misalnya, sebagai negara pendatang baru (late comer) dalam kemajuan industri dan ekonomi memulai upaya mengejar ketertinggalannya dari negara-negara yang telah lebih dahulu mencapai kemajuan ekonomi dan industri (fore runners) seperti Jerman, perancis dan Amerika dengan cara memacu pengembangan SDM.

Pengembangan SDM pada intinya diarahkan dalam rangka meningkatkan kualitasnya, yang pada gilirannya akan dapat meningkatkan produktivitas. Hasil berbagai studi menunjukkan, bahwa kualitas SDM merupakan faktor penentu produktivitas, baik secara makro maupun mikro. Sumber Daya Manusia (SDM) secara makro adalah warga negara suatu bangsa khususnya yang telah memasuki usia angkatan kerja yg memiliki potensi untuk berperilaku produktif (dengan atau tanpa pendidikan formal) yg mampu memenuhi kebutuhan hidup sendiri dan keluarganya yang berpengaruh pada tingkat kesejahteraan masyarakat di lingkungan bangsa atau negaranya.

Kualitas SDM sangat dipengaruhi oleh kualitas kesehatan (fisik dan psikis), kualitas pendidikan informal dan formal (yang berhubungan dengan keterampilan/keahlian kerja), kepribadian terutama moral/agama, tingkat kesejahteraan hidup dan ketersediaan lapangan kerja yang relevan. Dalam konteks lain, Sumber Daya Manusia adalah manusia/orang yang bekerja di lingkungan sebuah organisasi yang disebut pegawai, karyawan, personil, pimpinan / manajer, pekerja, tenaga kerja, majikan buruh dll. Di lingkungan organisasi bidang pendidikan adalah semua pegawai administratif, pendidik /guru, dosen serta tenaga kependidikan lainnya.

Dalam melakukan pengembangan SDM mempunyai ruang lingkup yang lebih luas terutama dalam hal meningkatkan pengetahuan, keterampilan, kemampuan, serta sikap atau tingkahlaku karyawan. Gouzali dalam Kadarisman mengemukakan pengembangan SDM (Sumber Daya Manusia) merupakan kegiatan yang harus 
dilaksanakan organisasi, agar pengetahuan (knowledge), Kemampuan (ability), dan keterampilan (skill) mereka sesuai dengan tuntutan pekerjaan yang mereka lakukan. ${ }^{1}$ Dengan kegiatan pegembangan ini, maka diharapkan dapat memperbaiki dan mengatasi kekurangan dalam melaksanakan pekerjaan dengan lebih baik, sesuai dengan perkembangan ilmu dan teknologi yang digunakan oleh organisasi. Menurut Mangkuprawira dalam Novita adanya pengembangan SDM yang baik menjadi suatu keharusan dalam sebuah institusi atau organisasi. ${ }^{2}$ Hal ini dapat dilakukan dengan strategi pengembangan Sumber Daya Manusia.

Pengembangan SDM pada intinya diarahkan dalam rangka meningkatkan kualitasnya, yang pada gilirannya akan dapat meningkatkan produktivitas. Hasil berbagai studi menunjukkan, bahwa kualitas SDM merupakan faktor penentu produktivitas, baik secara makro maupun mikro. Sumber Daya Manusia (SDM) secara makro adalah warga negara suatu bangsa khususnya yang telah memasuki usia angkatan kerja yg memiliki potensi untuk berperilaku produktif (dengan atau

\footnotetext{
${ }^{1}$ Kadarisman.M. Manajemen Pengembangan Sumber Daya manusia. Jakarta: PT. Raja Grafindo Persada. 2013.

${ }^{2}$ Novita V. Strategi Pengembangan Sumberdaya Manusia Di Bank Danamon. Skripsi. Fakultas Ekonomi Universitas Katolik Soegijapranata. Semarang. 2008.
}

tanpa pendidikan formal) yg mampu memenuhi kebutuhan hidup sendiri dan keluarganya yang berpengaruh pada tingkat kesejahteraan masyarakat di lingkungan bangsa atau negaranya.

Dalam melakukan pengembangan SDM ada beberapa pendekatan diantaranya melalui pendekatan motivasi, karena seorang individu, pegawai juga mempunyai sesuatu yang utama mengenai perilaku, sikap, tabiat dan kebiasaan- kebiasaan yang tumbuh dan berkembang yang dibentuk oleh kondisi lingkungan dan pengalamanpengalaman di tempat kerjanya. Tujuan organisasi akan sulit dicapai, bila para pegawai tidak mau menggali potensi yang ada dalam dirinya untuk bekerja semaksimal mungkin. Dengan kata lain pemberian motivasi oleh organisasi adalah agar pegawai tetap bekerja dengan baik dan selalu memberikan prestasi yang terbaik bagi organisasi. Menjadi kewajiban dari setiap pemimpin untuk mendorong dan memotivasi setiap bawahannya untuk berprestasi. Karyawan sangat berperan dalam mengembangkan kegiatan institusi sebagai tenaga operasional teknologi dan produksi. Dalam proses perkembangannya, motivasi diperlukan oleh karyawan dalam menunjang dan meningkatkan produktivitas kerja karyawan. Memotivasi karyawan dilakukan untuk menjaga keseimbangan atau mengantisipasi penurunan prestasi 
kerja yang diakibatkan oleh kegiatan yang monoton.

Dengan melihat tingkat turnover karyawan dan tingkat absensi yang cukup tinggi, maka menjadi masalah bagi institusi, apalagi kalau terjadi frustasi kerja dan stagnasi kinerja karyawan yang berakibat menurunnya tingkat produktivitas karyawan. Karena itulah masalah ini berdampak negatif terhadap kinerja yang berupa penurunan hasil produksi, kualitas produk, padahal apabila kalau dilihat dari biaya yang dikeluarkan adalah sama dengan apabila karyawan tersebut menggunakan kapasitas kerja yang optimal. Hal ini diduga adanya motivasi karyawan yang rendah, sehingga tingkat turnover dan kinerja karyawan rendah.

\section{KAJIAN TEORI}

\section{Pengertian Motivasi}

Motivasi adalah kesediaan melakukan usaha tingkat tinggi guna mencapai sasaran organisasi, yang dikondisikan oleh individu. Meskipun secara umum, motivasi merujuk ke upaya yang dilakukan guna mencapai setiap sasaran, di sini kita merujuk ke sasaran organisasi karena fokus kita adalah perilaku yang berkaitan dengan sasaran organisasi yang berkaitan degan kerja. Ada tiga unsur kunci dalam definisi itu: upaya, sasaran organiasi, dan kebutuhan.
Unsur upaya merupakan ukuran intensitas atau dorongan. Seseorang yang termotivasi, untuk dia berusaha keras. Tetapi tingkat upaya yang tinggi tidak selalu menghasilkan kinerja yang mengutungkan organisasi. Kebutuhan, mengacu ke keadaan batin yang membuat hasil-hasil tertentu tanpak menarik. Kebutuhan yang tidak terpuaskan menciptakan ketegangan yang merangsang dorongan di dalam diri seseorang. Dorongan itu menimbulkan perilaku pencarian untuk menemukan sasaran tertentu yang, jika tercapai, akan memuaskan kebutuhan itu dan menurunkan ketegangan tadi.

Menurut Nawawi Motivasi berarti suatu kondisi yang mendorong atau menjadi sebab seseorang melakukan suatu perbuatan/kegiatan, yang berlangsung secara sadar. ${ }^{3}$ Menurut Rivai dalam Kadarisman motivasi adalah serangkaian sikap dan nilai-nilai yang memengaruhi individu untuk mencapai hal yang spesifik sesuai dengan tujuan individu. ${ }^{4}$ Sikap dan nilai tersebut merupakan suatu yang invisible yang memberikan kekuatan untuk mendorong individu untuk bertingkah laku dalam mencapai tujuan.

${ }^{3}$ Nawawi H. Manajemen Sumberdaya Manusia untuk bisnis yang kompetitif. Yogyakarta. Gajah Mada University Press. 2011.

${ }^{4}$ Kadarisman. M,...,2013. 
Motivasi kerja secara umum dapat diidentifikasikan sebagai serangkaian kekuatan penggerak yang muncul dari dalam dan diluar diri masing-masing individu. Kedua kekuatan itu menimbulkan minat kerja dan berhubungan dengan tingkah laku dan menentukan arah, intensitas dan durasi dari tingkah laku atau kebiasaan individual Hasibuan dalam Chandra. ${ }^{5}$

\section{1) Teori Motivasi Kerja}

Dalam hal ini, terdapat 6 (enam) teori motivasi dari sudut psikologi yang dapat di implementasikan dalam pengembangan SDM yaitu: ${ }^{6}$

\section{a) Teori kebutuhan (need) dari Abraham}

\section{Maslow}

Setiap manusia memiliki kebutuhan, dalam teori ini kebutuhan diartikan sebagai kekuatan/tenaga (energi) yang mengahasilkan dorongan bagi individu untuk melakukan kegiatan agar dapat memenuhi atau memuaskan kebutuhan tersebut.
Gambar 1. Tingkat kebutuhan dalam teori Maslow

Keterangan:

1. Kebutuhan fisiologi merupakan kebutuhan mendasar seperti: makanan, air, rumah, tidur dan lain-lain.

2. Kebutuhan akan keamanan adalah kebutuhan akan suasana lingkungan yang aman dan bebas dari gangguan.

3. Kebutuhan pada lingkungan sosial, misalnya: agar dirinya diterima oleh kelompoknya, persahabatan, cinta, rasa kebersamaan dan membantu orang lain.

4. Kebutuhan akan Ego adalah kebutuhan akan penghargaa/ rasa hormat dari orang lain, pengakuan status, rasa berguna dan lain-lain.

5. Kebutuhan Perwujudan Diri seseorang merupakan kebutuhan tertinggi. Kebutuhan ini adalah perwujudan diri seseorang akan suatu prestasi, pemenuhan diri, peluang untuk berkembang lebih lanjut dari pernyataan dir.

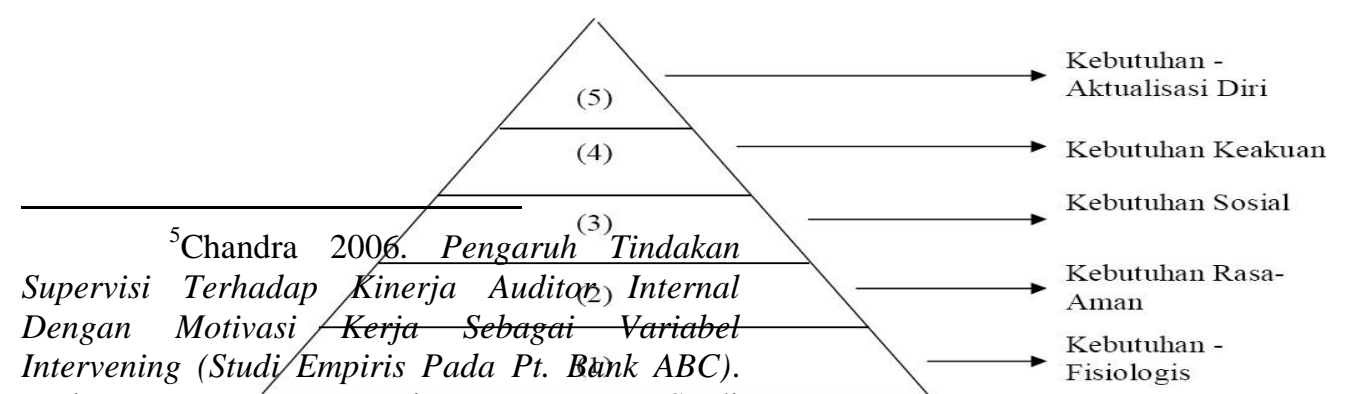

Tesis. Program Pascasarjana. Program Studi Magister Sains Akuntansi. Universitas Diponegoro. Semarang.

${ }^{6}$ Nawawi H. Manajemen Sumberdaya Manusia untuk bisnis yang kompetitif. Yogyakarta. Gajah Mada University Press. 2011.
Dalam teori ini menunjukkan kebutuhan itu bersifat bertingkat yang secara berurutan berbeda kekuatannya 
dalam memotivasi suatu kegitan termasuk juga bekerja.

\section{b) Teori dua faktor dari Frederick}

\section{Herzberg}

Teori ini meliputi :

a. Faktor sesuatu yang dapat memotivasi (Motivating factor)

1) kesempatan

untuk berprestasi(achievement)

2) pengakuan dalam lingkungan pekerjaan (recognition)

3) kesempatan untuk bertanggungjawab (responsibility)

4) kesempatan untuk berkembang dan mengembangkan diri (advancement and growth)

b. Kebutuhan kesehatan lingkungan kerja (Hygiene Factors)

1) kebutuhan akan kebijakan dan administrasi institusi yang jelas dan adil (company policy and administration)

2) supervisi yang memadai (supervision)

3) keserasian hubungan dengan supervisi (relationship with supervision)

4) kondisi pekerjaan yang kondusif (working condition)

5) gaji atau upah yang layak (salary)

6) hubungan yang baik antar pekerja (relationship with peers)
7) adanya penghargaan terhadap kehidupan pribadi (personal life)

8) hubungan yang serasi dengan bawahan (relationship with subordinates)

9) kejelasan status pekerjaan (job status)

10) masa depan dari pekerjaan yang dijalani (job safety)

Dalam implementasinya teori ini menekankan pentingnya keseimbangan antara dua faktor tersebut salah satu diantaranya tidak terpenuhi maka akan mengakibatkan pekerjaan menjadi tidak efektif dan tidak efisien.

c) Teori Penguatan (Reinforcement)

1) Teori ini didasarkan atas "hukum pengaruh"

2) Perilaku merupakan fungsi dari konsekuensinya

3) Tingkah laku dengan konsekuensi positif cenderung untuk diulang, sementara tingkah laku dengan konsekuensi negatif cenderung untuk tidak diulang.

\section{d) Teori Harapan (Expectancy)}

Teori ini menunjukkan

kecenderungan bertindak agar sesuai dengan harapan yang realistis yang tidak berlebihan. Harapannya tidak melampaui usaha yang dapat dilakukannya sesuai dengan kemampuan yang dimiliki. 


\section{e) Teori Prestasi (Achievement) dari} McClelland

Teori ini menggambarkan kebutuhan berprestasi merupakan motivasi dalam melaksanakan pekerjaan. Clelland dalam Kadarisman mengatakan bahwa manusia pada dasarnya mempunyai kemampuan untuk berprestasi diatas kemampuan orang lain. $^{7}$

\section{f) Teori Tujuan sebagai Motivasi}

1) Kuat lemahnya tingkah laku manusia ditentukan oleh sifat tujuan yang hendak dicapai.

2) Kecenderungan manusia untuk berjuang lebih keras mencapai suatu tujuan, apabila tujuan itu jelas, dipahami dan bermanfaat.

3) Makin kabur atau makin sulit dipahami suatu tujuan, akan makin besar keenganan untuk bertingkah laku.

4) Tujuan yang khusus akan menghantar kepada kinerja yang lebih tinggi.

Berdasarkan uraian mengenai teori motivasi dapat diketahui bahwa motivasi memiliki peranan yang sangat penting dalam meningkatkan kinerja karyawan karena dengan motivasi yang tinggi akan meningkatkan produktifitas kerja yang tinggi serta akan mengahsilkan proses

${ }^{7}$ Kadarisman...,2013. produksi yang efektif dan efisien sehinggga tujuan dari institusi dapat tercapai.

Motivasi kerja sangat penting ditumbuhkan bagi karyawan karena banyak sekali karyawan yang belum memahami akan arti pentingnya bekerja dengan baik dan benar, masih banyak karyawan yang hanya bekerja sebatas untuk mendapatkan upah saja tidak memiliki cita-cita yang tinggi dan ingin menjadi sumber daya manusia yang unggul dan bisa bersaing. Banyaknya turnover karyawan terjadi disebabkan karena ingin mendapatkan kesuksesan dengan instant tanpa di iringi dengan kerja keras, banyak memilki keluhan-keluhan terhadap profesi yang dikerjakannya sehingga daya juangnya sangat rendah, oleh karena itu perlu diberikan kesadaran berupa pentingnya manfaat atau makna pekerjaan yang dilaksanakannya guna memenuhi kebutuhan hidup serta memberikan harapan akan kesuksesan suatu saat kelak apabila dilaksanakan dengan sunguh-sungguh. Motivasi yang tumbuh didalam diri pekerja sebagai individu ini disebut dengan istilah motivasi intrinsik. Sedangkan motivasi yang bersumber dari luar pekerja sebagai individu adalah motivasi ekstrinsik, seperti adanya jabatan/posisi, upah atau gaji yang tinggi, pujian hukuman dan lain sebagainya. Berdasarkan keterangan tersebut diketahui motivasi memiliki duabentuk yaitu motivasi 
eksntrinsik (dari luar) dan motivasi dokumentasi. ${ }^{10}$ Yang berasal dari bukuinstrinsik diri buku atau dokumen-dokumen yang seseorang/(kelompok). ${ }^{8}$

\section{METODE PENELITIAN}

Jenis penelitian ini adalah penelitian kualitatif. Yang dimaksud dengan penelitian kualitatif yaitu jenis penelitian yang bertujuan untuk mendeskripsikan secara sistematis faktual dan menggambarkan fenomena secara detail. Arikunto menyatakan bahwa penelitian deskriptif merupakan penelitian yang dimaksud untuk mengumpulkan informasi mengenai status suatu gejala yang ada, yaitu keadaan gejala menurut apa adanya pada saat dilaksanakan penelitian. ${ }^{9}$ Adapun sumber data yang digunakan dalam penulisan ini adalah sumber data primer dan sumber data sekunder. Yang menjadi sumber data primer dalam penelitian ini adalah data yang diperoleh secara langsung mengenai hal- hal yang berkaitan dengan penelitian ini yaitu mengenai pengembangan sumber daya manusia di IAIN Bengkulu. Sedangkan sumber data sekunder dalam penelitian ini adalah sumber data yang mendukung berupa

\section{${ }^{8}$ Fahmi Perilaku Organisasi Teori,} Aplikasi Dan Kasus. Bandung. Penerbit Alfabeta. 2013.

${ }^{9}$ Suharsimi Arikunto, Prosedur Penelitian Suatu Pendekatan Praktek, Rineka Cipta,Jakarta; 1998. hlm. 121

berkaitan dengan penelitian ini.

Untuk mendapatkan dan menghimpun data di lapangan peneliti menggunakan beberapa tekhnik pengumpulan data, yaitu: Observasi, merupakan teknik pengumpulan data dengan cara pengamatan secara langsung ataupun tidak langsung terhadap objek penelitian. ${ }^{11}$ Dalam hal ini yang menjadi objek penelitian adalah sumber daya manusia yang ada di lingkungan IAIN Bengkulu. Wawancara, dalam proses wawancara ada dua pihak yang menempati kedudukan yang berbeda yaitu "pewawancara (interviewer) sebagai pengejar informasi atau yang mengajukan pertanyaan dan pihak yang diwawancarai (interviewee) sebagai pemberi informasi atau yang memberikan jawaban atas pertanyaan yang diajukan tersebut". ${ }^{12}$ Metode wawancara adalah suatu metode pengumpulan data dengan jalan wawancara yaitu mendapatkan informasi dengan cara bertanya langsung dengan responden. Wawancara yang digunakan dalam penelitian ini adalah wawancara terstruktur. Wawancara terstruktur merupakan "wawancara yang pewawancaranya menetapkan sendiri masalah dan pertanyaan yang akan disajikan, sama untuk setiap subyek penelitian". ${ }^{13}$

\footnotetext{
${ }^{10}$ Sanapiah faisal, Metodolgi penelitian Pendidikan, Usaha Nasional, Jakarta,2004

${ }^{11}$ Ibid, Hal. 51

12 Kartini Kartono, Pengantar Metodologi Riset Sosial. Cetakan VII Mandar, Bandung: 1996, Hal. 187.

${ }^{13}$ Moleong, Op. Cit., Hal. 128.
} 
PEMBAHASAN

\section{Pengembangan Sumber Daya Manusia}

Melalui Pendektan Motivasi kerja

\section{Faktor - Faktor Yang Mempengaruhi}

\section{Motivasi Kerja}

Motivasi kerja seorang karyawan dapat dipengaruhi oleh beberapa faktor seperti :

\section{a. Faktor kebutuhan manusia}

1) Kebutuhan dasar ( ekonomis )

Kebutuhan dasar yang dimaksud disini adalah kebutuhan akan makanan, pakaian, dan perumahan yang biasa disebut sebagai kebutuhan primer. Untuk memenuhi kebutuhan dasar ini sesorang akan bekerja keras dengan mengerahkan segala kemampuannya, karena kebutuhan makanan, pakaian, dan perumahan merupakan kebutuhan yang paling mendasr yang harus di penuhi.

2) Kebutuhan rasa aman (psikologis) Yang termasuk dalam kategori kebutuhan psikologis disini diantaranya adalah kebutuhan akan status, pengakuan, penghargaan, dan lain - lain.

3) Kebutuhan sosial

Menurut Robert Carison: "Satu cara meyakinkan para karyawan betah bekerja adalah dengan meyakinkan bahwa dirinya

$$
\begin{aligned}
& \text { memiliki banyak mitra di } \\
& \text { organisasi“. Karyawan dalam suatu } \\
& \text { organisasi } \\
& \begin{array}{l}
\text { memerlukan } \\
\text { berinteraksi dengan }
\end{array} \\
& \text { karyawan dan desama } \\
& \text { atasannya serta menumbuhkan } \\
& \text { pengakuan atas prestasi kerjanya. }
\end{aligned}
$$

\section{b. Faktor Kompensasi}

Kompensasi adalah segala sesuatu yang diterima para karyawan sebagai balas jasa bekerja. Apabila kompensasi diberikan secara benar, para karyawan akan lebih terpuaskan dan termotivasi untuk mencapai sasaran - sasaran organisasi. Kompensasi penting bagi karyawan, karena kompensasi mencerminkan nilai karya karyawan itu sendiri, keluarga, dan masyarakat. Dalam hal pemberian kompensasi terdapat beberapa faktor yang harus diperhatikan,diantaranya :

1) Arti gaji bagi karyawan

Bagi seorang karyawan gaji mempunyai arti yang mendalam, yakni sesuatu yang dapat mempengaruhi tingkat kehidupan karyawan yang bersangkutan bersama keluarganya.

2) Dasar pemberian gaji

Salah satu dasar pemberian gaji atau kompensasi adalah " hasil kerja " yakni gaji diberikan berdasarkan jumlah atau nilai barang yang dijual atau yang dihasilkan. 


\section{c. Faktor Komunikasi}

Komunikasi yang lancar adalah komunikasi terbuka dimana informasi mengalir secara bebas dari atas ke bawah atau sebaliknya, Dalam suatu organisasi komunikasi perlu dijalin secara baik antara atasan dengan bawahan atau sesama bawahan, karena dengan komunikasi yang lancar maka arus komunikasi akan berjalan lancar pula serta tidak terjadi adanya mis komunikasi yang akan mengakibatkan kesimpang siuran dalam melaksanakan pekerjaan dalam organisasi. Dengan komunikasi yang lancar kebijakan organisasi akan dapat lebih mudah dimengerti.

\section{d. Faktor Kepemimpinan}

Kepemimpinan adalah kemampuan seseorang untuk memguasai atau mempengaruhi orang lain atau masyarakat yang berbeda - beda menuju pencapaian tertentu. Dalam mencapai tujuan yakni untuk dapat menguasai atau mempengaruhi serta memotivasi orang lain, maka dalam penerapan manajemen sumber daya manusia digunakan beberapa gaya kepemimpinan, diantaranya :

1) Democratic Leadership

2) padalah suatu gaya kepemimpinan yang menitikberatkan kepada kemampuan untuk menciptakan moral dan kemampuan untuk menciptakan Kepercayaan.
3) Dictatorial atau autocratic Leadership

yakni suatu gaya Leadership yang menitikberatkankepada

kesanggupan untuk memaksakan keinginannya yang mampu mengumpulkan pengikut pengikutnya untuk kepentingan pribadinya dan / atau golongannya dengan kesediaan untuk menerima segala resiko apapun.

4) Paternalistik Leadership yakni bentuk antara gaya pertama (democratic) dan kedua (dictatorial ) diatas.

5) Free Rain Leadership yaitu salah satu gaya kepemimpinan yang $100 \%$ menyerahkan sepenuhnya seluruh kebijaksanaan pengoperasian manajemen sumber daya manusia kepada bawahannya dengan hanya berpegang kepada ketentuan - ketentuan pokok yang ditetapkan oleh atasan mereka.

\section{e. Faktor pelatihan}

Pelatihan merupakan suatu sarana untuk meningkatkan kemampuan karyawan dalam suatu organisasi. Untuk lebih meningkatkan kualitas sumber daya manusia setiap organisasi perlu melaksanakan pendidikan dan pelatihan bagi karyawannya, baik yang diselenggarakan di dalam maupun di luar 
organisasi. Manfaat pelatihan bagi organisasi. Hal ini merupakan sumber karyawan adalah :

1) Meningkatkan motivasi motivasi kerja yang sangat mempengaruhi

2) Meningkatkan pengetahuan, kemmapuan, dan ketrampilan dalam melaksanakan tugas sehari - hari.

3) Meningkatakn rasa percaya diri dan menghilangkan rasa rendah diri

4) Memperlancar pelaksanaan tugas

5) Menumbuhkan sikap positif terhadap organisasi

6) Meningkatkan semangat dan gairah kerja

7) Mempertinggi rasa peduli terhadap organisasi

8) Meningkatkan rasa saling menghargai antar karyawan

9) Memberikan dorongan bagi karyawan untuk menghasilkan yang terbaik

10) Memberikan dorongan bagi karyawan untuk memberikan pelayanan yang terbaik.

\section{f. Faktor Prestasi}

Penilaian presasi kerja karyawan bagi organisasi merupakan sarana untuk mengembangkan sumber daya manusia. Sedangkan bagi karyawan penilaian prestasi dapat memacu semangat kerja, guna peningkatkan kinerja selanjutnya. Karena dengan penilaian prestasi ini akan merasa bahwa hasil kerja mereka diakui oleh pihak organisasi dan kemudian menimbulkan harapan untuk memperoleh kompensasi dari kinerja karyawan.

\section{2) Pengembangan Sumber daya Manusia} dengan Teknik Motivasi

a) Pendekatan Pekerja

Ada beberapa teknik memotivasi dengan pendekatan pekerja diantaranya :

1) Pendekatan Tadisional ("Be Strong”)

Teknik ini dilakukan dengan cara melakukan pemaksaan, pengawasan secara ketat, Perilaku pekerja diarahkan dengan insentif dan ancaman hukuman serta tugas dibuat dalam operasi-operasi yang sederhana dan mudah dipelajari.

2) Pendekatan Human Relations ("Be Good")

Pendekatan dengan cara memberikan otonomi, rasa tanggungjawab. Adanya keterlibatan, pemberdayaan, kesempatan untuk berkembang, Meaningful \& Challenging Works.

3) "Implicit Bargaining"

a) Merupakan kombinasi pendekatan tradisional dan pendekatan human relations.

b) Dalam pendekatan ini selain adanya aturan formal menyangkut pekerja juga adanya perjanjian yang tidak 
tertulis antara pekerja dan pihak pimpinan mengenai hal-hal apa yang menjadi tugas dan yang harus dikerjakan oleh pekerja.

4) Kompetisi

- Menciptakan situasi persaingan diharapkan motivasi kerja akan bertambah besar.

- Dalam menciptakan situasi persaingan digunakan Insentif.

- Insentif : Faktor-faktor eksternal yang oleh individu dipandang dapat memenuhi atau memuaskan kebutuhankebutuhan yang dirasakannya.

5) Motivasi Internal

- Self-Motivation, SelfManagement

- Dalam pendekatan ini motivasi pekerja diupayakan bangkit dari dalam diri pekerja sendiri (Kesadaran).

- Pendekatan ini relatif lebih sulit, namun lebih effektif jika mampu dilakukan.

- Proses pembelajaran dan Effektivitas peran atasan sangat menentukan keberhasilan pendekatan ini.

\section{b) Pendekatan Pekerjaan}

Ada beberapa teknik memotivasi dengan pendekatan pekerja diantaranya :
- Pendekatan ini berangkat dari asumsi bahwa waktu siklus yang pendek, dan pekerjaan yang monoton akan membuat pekerja cepat merasa bosan, yang akan berakibat pada rendahnya produktivitas.

- Treatmentnya : Horizontal Job Loading (Quantity)

- Semakin banyak kegiatan yang harus dilakukan akan memperpanjang waktu siklus, akan menghindari cepat munculnya rasa bosan.

\section{Job Rotation}

- Pendekatan inipun bertujuan untuk menghindari tumbuhnya rasa bosan dalam diri pekerja.

- Cara yang ditempuh adalah melakukan perputaran (rotasi) kerja.

- Teknik memotivasi ini terkait dengan pengelolaan fungsi SDM yaitu Placement / Kebijakan Karir.

\section{Job Enrichment}

- Berbeda dengan pendekatan "Job Enlargement".

- Treatmentnya : Vertical Job Loading

- Yang ditambahkan unsur kualitas dari isi pekerjaan. 
- Isi pekerjaan adalah unsurunsur "Motivator"

\section{Goal Setting}

- Pendekatan ini berangkat dari asumsi bahwa motivasi kerja akan meningkat bilamana apa yang menjadi sasaran kerjanya jelas.

- Motivasi akan lebih meningkat lagi, bilamana dalam penetapan sasaran kerja ini para karyawan turut dilibatkan.

- Dua faktor Challenging Work

Involvement.

\section{Job Engineering}

- Dasar dari pendekatan ini adalah memperhatikan faktorfaktor teknis pelaksanaan pekerjaan.

- Termasuk disini adalah memperhatikan : teknik tata cara / metoda kerja, desain peralatan kerja dan kondisi fisik lingkungan kerja

\section{Sociotechnical Approach}

- Dasar dari pendekatan ini adalah melihat organisasi sebagai suatu sistem yang terdiri dari komponen sosial dan teknologik.
- Pendekatan ini memperhatikan interface antara sistem teknologik dan sistem sosial.

Berdasarkan permasalahan yang ada mengenai rendahnya motivasi sehingga menimbulkan rendahnya produktivitas karena motivasi dan produktivitas adalah suatu bagian yang saling terkait satu samalainnya, peningkatan motivasi kerja akan mempengaruhi peningkatan produktivitas dan begitu pula sebaliknya. ${ }^{14}$

\section{KESIMPULAN}

Dalam melakukan pengembangan SDM mempunyai ruang lingkup yang lebih luas terutama dalam hal meningkatkan pengetahuan, keterampilan, kemampuan, serta sikap atau tingkahlaku karyawan. pengembangan SDM (Sumber Daya Manusia) merupakan kegiatan yang harus dilaksanakan organisasi, agar pengetahuan (knowledge), Kemampuan (ability), dan keterampilan (skill) mereka sesuai dengan tuntutan pekerjaan yang mereka lakukan. Dengan kegiatan pegembangan ini, maka diharapkan dapat memperbaiki dan mengatasi kekurangan dalam melaksanakan pekerjaan dengan lebih baik, sesuai dengan perkembangan ilmu dan teknologi yang digunakan oleh organisasi.

${ }^{14}$ Fahmi..., 2013 
Pengembangan SDM yang baik menjadi suatu keharusan dalam sebuah organisasi. Hal ini dapat dilakukan dengan strategi pengembangan Sumber Daya Manusia. Pengembangan SDM memiliki peranan penting dalam meningkatkan kinerja dan produktivitas karyawan. Dalam melakukan pengembangan SDM bisa dilakukan dengan menggunkan pendekatan motivasi kerja. Dalam motivasi kerja terdapat 6 teori motivasi diantaranya : Teori kebutuhan (need) dari Abraham Maslow, (b) Teori dua faktor dari Frederick Herzberg, (c) Teori Prestasi (Achievement) dari McClelland, (d) Teori Penguatan (Reinforcement), (e) Teori Harapan (Expectancy), (f) Teori Tujuan sebagai Motivasi. Berdasarkan teori tersebut seorang pimpinan bisa melakukan berbagai hal guna meningkatkan motivasi kerja karyawan serta berupaya meningkatkan produktivitas kerja karena dengan motivasi yang tinggi maka produktivitas kerja juga akan tinggi begitu pula sebaliknya karena diantara keduanya akan saling berkaitan, dimana motivasi kerja merupakan dorongan untuk melakukan sesuatu tindakan secara sadar yang muncul dari dalam dan diluar diri masing-masing individu dengan tujuan meningkatkan SDM yang unggul dan berdaya saing.

\section{DAFTAR PUSTAKA}

Chandra 2006. Pengaruh Tindakan Supervisi Terhadap Kinerja Auditor Internal Dengan Motivasi Kerja Sebagai Variabel Intervening (Studi Empiris Pada Pt. Bank ABC). Tesis. Program Pascasarjana. Program Studi Magister Sains Akuntansi. Universitas Diponegoro. Semarang. Dessler, Gary. 2010. Manajemen Sumber Daya Manusia edisi kesepuluh jilid 1. Jakarta:PT.Indeks

Fahmi 2013. Perilaku Organisasi Teori, Aplikasi Dan Kasus. Bandung. Penerbit Alfabeta.

Kadarisman. M. 2013. Manajemen

Pengembangan Sumber Daya

manusia.

Jakarta. PT. Raja Grafindo Persada.

Nawawi H. 2011. Manajemen Sumberdaya

Manusia untuk bisnis yang kompetitif.

Yogyakarta. Gajah Mada University

Press.

Noe, R. A et all. 2014. Manajemen Sumberdaya Manusia Mencapai Keunggulan Bersaing. Jakarta. Penerbit Salemba Empat.

Novita V. 2008. Strategi Pengembangan

Sumberdaya Manusia Di Bank

Danamon. Skripsi. Fakultas Ekonomi Universitas Katolik Soegijapranata. Semarang. 